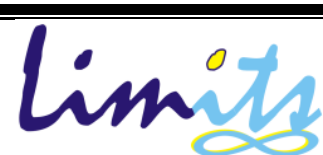

Limits: Journal of Mathematics and Its Applications

E-ISSN: $2579-8936$

P-ISSN: $1829-605 \mathrm{X}$

Vol. 16, No. 2, Desember 2019, 135-146

DOI: http://dx.doi.org/10.12962/limits.v16i2.5940

\title{
Bilangan Dominasi Graf Hasil Operasi Korona Sisi
}

\author{
Yayuk Wahyuni ${ }^{1 *}$, Mohammad Imam Utoyo ${ }^{2}$, Slamin $^{3}$ \\ ${ }^{1,2}$ Departemen Matematika, Fakultas Sains dan Teknologi, Kampus C Universitas Airlangga, \\ Jl. Mulyorejo, Surabaya \\ ${ }^{3}$ Program Studi Informatika Universitas Jember; Jl Kalimantan 37 Jember \\ *e-mail: yayuk-w@,fst.unair.ac.id
}

\begin{abstract}
Abstrak
Diberikan dua graf $G$ dan $H$. Misalkan graf $G$ mempunyai $n$ titik dan $m$ sisi. Operasikorona sisi (edge corona) dari dua graf $G$ dan $H$, didefinisikan sebagai graf yang diperoleh dari satu salinan graf $G$ dan $m$ salinan graf $H$ dan menghubungkan dua titik dari sisi ke- $i$ pada graf $G$ ke setiap titik dari salinan ke- $i$ dari graf $H$. Penelitian ini bertujuan untuk menentukan bilangan dominasi dari graf hasil operasi korona sisi antara graf-graf tertentu dengan sebarang graf dan menentukan karakter graf yang bilangan dominasi hasil korona sisinya bernilai sama dengan bilangan dominasi graf induknya. Selain itu, pada penelitian ini juga dikaji nilai bilangan dominasi jarak-2 graf hasil operasi korona sisi beserta karakter graf yang mempunyai bilangan dominasi jarak-2 sama antara graf hasil operasi korona sisinya dengan graf induknya.
\end{abstract}

Kata Kunci: Bilangan dominasi, bilangan dominasi jarak-2, korona sisi, himpunan dominasi.

\begin{abstract}
Given two graphs $G$ and $H$. Let $G$ be a graph with $n$ vertices and medges. The edge corona of two graphs $G$ and $H$ is defined as a graph obtained by taking one copy of $G$ and $m$ copies of $H$ and then joining two end-vertices of the $i$-th edge of $G$ to every vertex of the $i$-th copy of $H$. The aims of this research were to determine the dominating number of the edge corona of a particular class of graph and any graph, and to determine the property of graph which its dominating number equal to the dominating number of its edge corona. This research also invetigated the distance-2 dominating number of the edge corona and its property when its distance-2 dominating number equal to the distance-2 dominating number of its edge corona.
\end{abstract}

Keywords:Dominating number, distance-2 dominating number, edge corona, dominating set.

\section{Pendahuluan}

Kajian tentang bilangan dominasi terkait operasi pada graf telah dilakukan oleh beberapa peneliti. Pavlic \& Zerovnik ([1]) telah menyusun algoritma untuk menentukan bilangan dominasi hasil kali Cartesian graf sikel dan graf lintasan yaitu graf $P_{n} \square C_{k}$ untuk $k \leq 11$, graf $C_{n} \square P_{k}$ untuk $k \leq 7$ dan graf $C_{n} \square C_{k}$ untuk $k \leq 7$. Selanjutnya Go \& Canoy Jr. ([2]) juga telah menentukan beberapa bilangan dominasi pada operasi korona antara lain dominasi biasa, dominasi total, dan 
dominasi Roman. Juga ada Klobucar ([3]) yang menentukan bilangan dominasi pada cardinal product untuk graf lintasan $P_{k} \times P_{n}$ untuk $2 \leq k \leq 5$ dan $n>1$. Sementara itu Kuziak et al. ([4]) juga telah menentukan beberapa bilangan dominasi untuk rooted product antara lain dominasi biasa, dominasi Roman, dominasi independen, dan dominasi terhubung. Sebagai pengembangan konsep bilangan dominasi, telah dikaji pula konsep dominasi jarak- $k$ yang penelitiannya antara lain telah dilakukan oleh Vaidya ([5]) untuk splitting graf yang dibentuk dari graf lintasan serta Prathibha ([6]) yang menulis tentang algoritma untuk menentukan himpunan dominasi jarak- $k$ dari graf bintang diperumum (extended star graph). Terinspirasi dari kajian-kajian tersebut, penelitian ini mengkaji pengembangan bilangan dominasi (biasa dan jarak-2) pada operasi korona sisi sebagai pengembangan dari operasi korona sebagaimana dibahas oleh Go \& Canoy di atas. Penelitian difokuskan untuk menentukan nilai bilangan dominasi (biasa) dan bilangan dominasi jarak-2 dari graf hasil operasi korona sisi pada graf-graf tertentu serta menentukan hubungan bilangan dominasi tersebut dengan bilangan dominasi graf induknya.

\section{Metode Penelitian}

Penelitian dilaksanakan dengan terlebih dahulu mengkonstruksi dan menghitung bilangan dominasi graf hasil operasi korona sisi dari graf-graf tertentu yaitu graf lintasan, graf sikel, graf lengkap, graf bipartit lengkap, graf multipartit lengkap, graf tangga, graf kembang api, dan graf pohon pisang dengan berbagai graf. Berikutnya merumuskan hasil yang telah diperoleh dan menyusun hipotesis untuk langkah pembuktian. Langkah selanjutnya menyusun dugaan tentang hubungan bilangan dominasi graf hasil operasi korona sisi dengan bilangan dominasi graf induknya yang diakhiri dengan pembuktian dugaan tersebut. Semua langkah tersebut diulang untuk bilangan dominasi jarak-2.

Berikut definisi bilangan dominasi yang memegang peranan penting dalam tulisan ini. Definisi 1[7] Suatu titik $v$ dalam $G$ dikatakan mendominasi (dominate) titik itu sendiri dan setiap titik yang bertetangga dengannya. Himpunan $S \subseteq V(G)$ disebut himpunan dominasi (dominating set) dari G jika setiap titik dari $G$ didominasi oleh paling sedikit satu titik dalam S. Kardinalitas minimum di antara himpunan dominasi dari $G$ dinamakan bilangan dominasi (dominating number) dari $G$, dinotasikan $\gamma(G)$. Himpunan dominasi dengan kardinalitas $\gamma(G)$ dinamakan himpunan dominasi minimum atau himpunan $-\gamma(G)$.

Dengan memperumum ketetanggaan pada definisi bilangan dominasi menjadi ketetanggaan jarak-2, diperoleh definisi bilangan dominasi jarak-2 
Definisi 2[8] Diberikan $G=(V, E)$ dan $S \subseteq V$. Himpunan $S$ dinamakan himpunan dominasi jarak-2 (distance-2 dominating set) jika setiap titik elemen $V \backslash S$ berada dalam jarak 2 dari paling sedikit satu titik dalam S. Kardinalitas minimum diantara himpunan dominasi jarak-2 pada G dinamakan bilangan dominasi jarak-2, dinotasikan $\gamma_{\leq 2}(G)$.

Sebagai pengembangan lebih lanjut dari operasi korona, didefinisikan operasi korona sisi yaitu mengganti peran titik pada graf pertama dengan sisi pada graf tersebut.

Definisi 3 [9] Misalkan $G$ dan $H$ adalah dua graf dengan titik-titikyang saling asing, berturutturut mempunyai $n_{1}$ dan $n_{2}$ titik serta $m_{1}$ dan $m_{2}$ sisi. Korona sisi (edge corona) dari $G$ dan $H$, dinotasikan dengan $G \diamond H$, didefinisikan sebagai graf yang diperoleh dari satu salinan graf $G$ dan $m_{1}$ salinan graf $H$ dan menghubungkan dua titik dari sisi ke-i pada graf $G$ ke setiap titik dari salinan ke-i dari graf $H$.

Definisi 3 di atas secara jelas menyatatakan bahwa $E(G) \neq \emptyset$. Banyaknya titik dan sisi pada graf hasil operasi korona sisi berturut-turut adalah $|V(G \diamond H)|=n_{1}+m_{1} n_{2}$ dan $|E(G \diamond H)|=$ $m_{1}+2 m_{1} n_{2}+m_{1} m_{2}$ Contoh graf hasil operasi korona sisi dari graf $C_{3}$ dan $P_{4}\left(C_{3} \diamond P_{4}\right)$ disajikan pada Gambar 1 berikut.

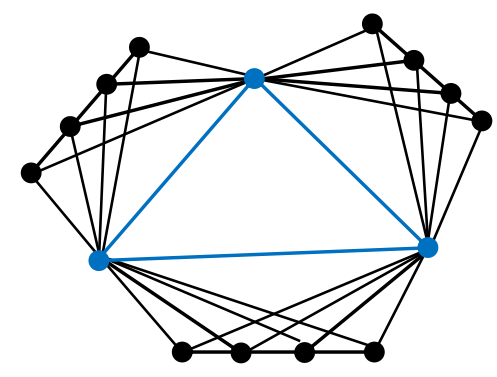

Gambar 1. Graf hasil operasi korona sisi $C_{3} \diamond P_{4}$

Untuk keperluan lebih lanjut, salinan ke- $i$ graf $H$ yang dihubungkan dengan sisi ke- $i$ (menghubungkan titik $v$ dan $w$ ) pada graf $G$, dinotasikan dengan $H_{e_{i}}$ atau $H_{v w}$. Selanjutnya subgraf yang diperoleh dengan menghubungkan sisi $e_{i}=v w$ dengan $H_{e_{i}}$ atau $H_{v w}$ dinotasikan dengan $\langle v\rangle+\langle w\rangle+H_{v w}$ atau $\langle v\rangle+\langle w\rangle+H_{e_{i}}$. Penulisan ini juga disajikan secara singkat sebagai $v+w+H_{v w}$ atau $v+w+H_{e_{t}}$. Titik $v$ yang bertetangga dengan titik $w$ ditulis sebagai $v \sim w$.

Beberapa graf tertentu yang dirujuk pada tulisan ini adalah graf lintasan $\left(P_{n}\right)$, graf sikel $\left(C_{n}\right)$, graf lengkap $\left(K_{n}\right)$, graf bipartit lengkap $\left(K_{m, n}\right)$, graf multipartit lengkap $\left(K_{n_{1}, n_{2}, \ldots, n_{k}}\right)$, graf tangga $\left(L_{n}\right)$, graf kembang api $\left(F_{n, k}\right)$, dan graf pohon pisang $\left(B_{n, k}\right)$.

Proposisi 1[3] $\gamma\left(P_{n}\right)=\left\lceil\frac{n}{3}\right\rceil$ dan $\gamma\left(C_{n}\right)=\left\lceil\frac{n}{3}\right\rceil$ untuk $n \geq 3$. 
Proposisi 2[8] Jika G graf dengan n titik maka $\left\lceil\frac{n}{1+\Delta(G)}\right\rceil \leq \gamma(G) \leq n-\Delta(G)$.

Proposisi 3[10] Untuk $n \geq 3$ berlaku $\gamma_{\leq 2}\left(P_{n}\right)=\gamma_{\leq 2}\left(C_{n}\right)=\left\lceil\frac{n}{5}\right\rceil$

\section{Hasil dan Pembahasan}

Pada operasi korona sisi $G \diamond H$, pada subgraf $v+w+H_{v w}$, titik $v$ atau titik $w$ yang merupakan titik pada graf induk $G$ mendominasi titik elemen $V(G)$ yang bertetangga dengannya dan semua titik elemen dari $V\left(H_{v w}\right)$. Sementara itu untuk sebarang $x \in V\left(H_{v w}\right)$, titik $x$ hanya mendominasi titik-titik elemen $V\left(H_{v w}\right)$ lain yang bertetangga dengan $x$ serta titik $v$ dan $w$ pada graf induk $G$. Hal tersebut dapat dilustrasikan pada gambar di bawah ini.

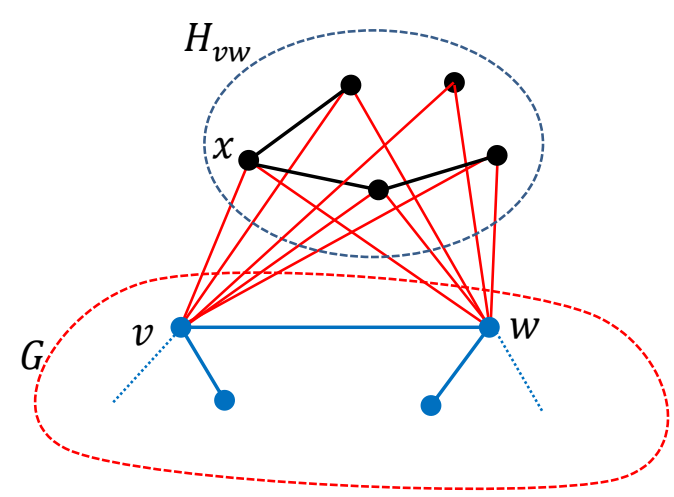

Gambar 2. Dominasi pada subgraf dari $G \diamond H$

Dengan gambaran itu, ketika menentukan himpunan dominasi dengan kardinalitas minimum, titik elemen $V(G)$ lebih dipilih karena mendominasi lebih banyak titik dibanding titik elemen $V\left(H_{v w}\right)$. Oleh karena itu himpunan- $\gamma(G \diamond H)$ hanya berasal dari elemen $V(G)$ saja. Lebih lanjut operasi korona sisi antara graf $G$ dan $H$ dapat terjadi untuk sebarang graf $H$. Dalam arti, jika $G$ graf terhubung sedang $H$ graf terhubung ataupun tidak terhubung akan diperoleh graf $G \diamond H$ yang merupakan graf terhubung.

Melengkapi hasil yang telah diperoleh pada Proposisi 1 - Proposisi 3, berikut beberapa hasil yang telah diperoleh.

Proposisi $4 \gamma\left(K_{n}\right)=1, \quad \gamma\left(K_{m, n}\right)=\gamma\left(K_{n_{1}, n_{2}, \ldots, n_{k}}\right)=2$ untuk $m, n, n_{i}>1, \quad \gamma\left(L_{n}\right)=\left\lceil\frac{n+1}{2}\right\rceil$, $\gamma\left(F_{n, k}\right)=n$, dan $\gamma\left(B_{n, k}\right)=\left\{\begin{array}{r}n, \text { untuk } k=2 \\ n+1, \text { untuk } k>2\end{array}\right.$.

Proposisi 5 Untuk $G$ graf berordo $n, \gamma(G)=1$ jika hanya jika terdapat graf $H$ sehingga $G=$ $K_{1}+H$. 
Proposisi $6 \quad \gamma_{\leq 2}\left(K_{n}\right)=\gamma_{\leq 2}\left(K_{m, n}\right)=\gamma_{\leq 2}\left(K_{n_{1}, n_{2}, \ldots, n_{k}}\right)=1, \quad \gamma_{\leq 2}\left(L_{n}\right)=\left\lceil\frac{n+1}{4}\right\rceil, \quad \gamma_{\leq 2}\left(F_{n, k}\right)=$ $\left\{\begin{array}{c}{\left[\begin{array}{c}n \\ 3\end{array}\right] \text {, untuk } k=2} \\ n \text {, untuk } k>2\end{array}\right.$, dan $\gamma_{\leq 2}\left(B_{n, k}\right)=\left\{\begin{array}{c}1, \text { untuk } k=2 \\ n, \text { untuk } k>2\end{array}\right.$

\subsection{Bilangan Dominasi Hasil Operasi Korona Sisi}

Beberapa bilangan dominasi hasil operasi graf-graf tertentu dengan sebarang graf disajikan pada subbab ini.

Teorema 1 Jika $P_{n}$ adalah graf lintasan dan $H$ adalah graf sebarang maka $\gamma\left(P_{n} \diamond H\right)=\left\lfloor\frac{n}{2}\right\rfloor$, untuk $n>1$.

Bukti: Misalkan $P_{n}$ untuk $n>1$ merupakan sebuah graf lintasan dengan himpunan titik $V\left(P_{n}\right)=$ $\left\{v_{1}, v_{2}, \ldots, v_{n}\right\}$ dan himpunan sisi $E\left(P_{n}\right)=\left\{e_{i}=v_{i} v_{i+1} ; i=1, \ldots, n-1\right\}$ dan $H$ merupakan graf sebarang. Diambil $S=\left\{v_{2 t} ; t=1, \ldots, k=\left\lfloor\frac{n}{2}\right\rfloor\right\}$. Untuk sebarang $x \in V\left(P_{n} \diamond H\right) \backslash S$ :

- Jika $n$ genap maka $x=v_{2 t-1}$ atau $x \in V\left(H_{e_{i}}\right)$ untuk $i=2 t-1,2 t$.

- Jika $n$ gasal maka $x=v_{2 t-1}$ atau $x=v_{2 k+1}$ atau $x \in V\left(H_{e_{i}}\right)$ untuk $i=2 t-1,2 t$.

Dalam $P_{n}$, jelas bahwa $v_{2 t-1} \sim v_{2 t}$ dan $v_{2 k+1} \sim v_{2 k}$. Sementara itu, untuk setiap $x \in V\left(H_{e_{2 t-1}}\right)$ atau $x \in V\left(H_{e_{2 t}}\right)$ maka $x \sim v_{2 t}$. Jadi $S$ merupakan himpunan dominasi. Andaikan ada $T \subseteq V\left(P_{n}\right)$ dengan $|T|<k=\left\lfloor\frac{n}{2}\right\rfloor$. Tanpa mengurangi keumuman bukti, jika $T=\left\{v_{2 t} ; t=1, \ldots, k-1\right\}$ maka untuk setiap $x \in V\left(H_{e_{2 k-1}}, x \sim v_{2 k-1}\right.$ tetapi $x \times v_{2(k-1)}$. Jika $T \neq\left\{v_{2 t} ; t=1, \ldots, k-1\right\}$ maka terdapat $H_{e_{i}}, 1 \leq i \leq n-1$, dengan $v_{i}, v_{i+1} \notin T$ sehingga setiap titik elemen $H_{e_{i}}$ tidak bertetangga dengan titik elemen $T$. Ini berarti $T$ bukan himpunan dominasi. Dengan demikian $S$ merupakan himpunan dominasi dengan kardinalitas minimum sehingga $\gamma\left(P_{n} \diamond H\right)=|S|=\left\lfloor\frac{n}{2}\right\rfloor$.

Dengan cara yang sama diperoleh pula hasil untuk graf sikel dan graf lengkap sebagaimana dijabarkan dalam teorema berikut.

Teorema 2. Jika $C_{n}$ adalah graf sikel, $K_{n}$ adalah graf lengkap dan $H$ adalah graf sebarang maka

(ii) $\quad\left(K_{n} \diamond H\right)=n-1$

Gambar 3 memperlihatkan bilangan dominasi graf hasil operasi korona sisi dari graf lintasan $P_{5}$ dan graf sikel $C_{5}$ dengan sebarang graf $H$. Dalam hal ini $\gamma\left(P_{5} \diamond H\right)=2$ sedang $\gamma\left(C_{5} \diamond H\right)=3$. 

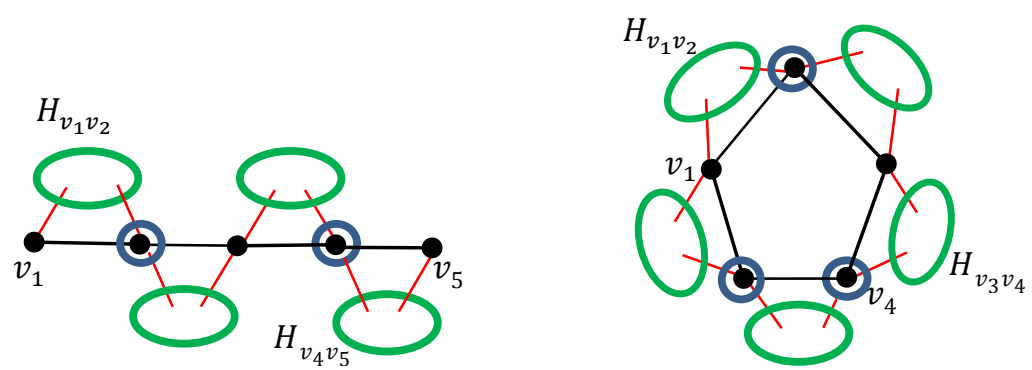

Gambar 3. Himpunan dominasi graf $P_{5} \diamond H$ dan $C_{5} \diamond H$

Teorema 3. Jika $K_{m, n}$ adalah graf bipartit lengkap dengan $1<m \leq n$ dan $H$ graf adalah sebarang maka $\gamma\left(K_{m, n} \diamond H\right)=m$.

Bukti: Misalkan $K_{m, n}$ merupakan graf bipartit lengkap dimana $V\left(K_{m, n}\right)=V_{1} \cup V_{2}$ dengan $V_{1}=$ $\left\{v_{1, i} ; i=1,2, \ldots, m\right\} \quad$ dan $\quad V_{2}=\left\{v_{2, j} ; j=1,2, \ldots, n\right\} \quad$ sementara $\quad E\left(K_{m, n}\right)=\left\{v_{1, i} v_{2, j} ; i=\right.$ $1,2, \ldots, m$ dan $j=1,2, \ldots, n\}$. Diambil $S=V_{1}$. Untuk sebarang $x \in V\left(K_{m, n} \diamond H\right) \backslash S$ maka $x \in$ $V\left(H_{v_{1, i} v_{2, j}}\right)$ atau $x \in V_{2}$. Jika $x \in V\left(H_{v_{1, i} v_{2, j}}\right)$ untuk $1 \leq i \leq m$ dan $1 \leq j \leq n$ maka $x \sim v_{1, i}$. Jika $x \in V_{2}$ maka $x \sim v_{1, i}$ untuk suatu $i$. Andaikan ada $i$ sehingga $v_{1, i} \notin S$ maka setiap $y \in V\left(H_{v_{1, i} v_{2, j}}\right)$ tidak bertetangga dengan titik anggota $S$ lainnya sehingga $S$ bukan himpunan dominasi.

Secara sama, diperoleh bilangan dominasi hasil operasi korona sisi dari graf tripartit lengkap $K_{n_{1}, n_{2}, n_{3}}$ dengan sebarang graf $H$ dimana $1<n_{1} \leq n_{2} \leq n_{3}$ yaitu $\gamma\left(K_{n_{1}, n_{2}, n_{3}} \diamond H\right)=$ $n_{1}+n_{2}$. Hasil ini dapat diperumum untuk graf multipartit lengkap.

Teorema 4. Jika $K_{n_{1}, n_{2}, \ldots, n_{k}}$ adalah graf multipartit lengkap dengan $1<n_{1} \leq \cdots \leq n_{k}$ dan $H$ adalah graf sebarang maka $\gamma\left(K_{n_{1}, n_{2}, \ldots, n_{k}} \diamond H\right)=\sum_{i=1}^{k-1} n_{i}$.

Teorema 5. Jika $L_{n}$ adalah graf tangga dan $H$ adalah graf sebarang maka $\gamma\left(L_{n} \diamond H\right)=n$ dengan $n>1$.

Bukti: Misalkan $L_{n}$ dengan $n>1$ merupakan sebuah graf tangga dengan himpunan titik $V\left(L_{n}\right)=$ $\left\{v_{1, i}, v_{2, i} ; i=1,2, \ldots n\right\}$ dan himpunan sisi $E\left(L_{n}\right)=\left\{v_{1, i} v_{1, i+1}, v_{2, i} v_{2, i+1} ; i=1, \ldots, n-1\right\} \cup$ $\left\{v_{1, i} v_{2, i} ; i=1, \ldots, n\right\}$ dan $H$ adalah graf sebarang. Misalkan $S$ himpunan dominasi pada $L_{n} \diamond H$. Untuk setiap dua titik pada graf induk $L_{n}$ sebagai calon himpunan- $\gamma\left(L_{n} \diamond H\right)$, terdapat dua kondisi yang tidak boleh terjadi, karena berakibat $S$ bukan himpunan dominasi, yaitu: 
(i) Jika titik $v_{1, i}, v_{2, i} \notin S$ untuk $1 \leq i \leq n$ maka titik-titik elemen $V\left(H_{v_{1, i} v_{2, i}}\right)$ tidak bertetangga dengan titik elemen $S$.

(ii) Jika titik $v_{j, i}, v_{j, i+1} \notin S$ untuk $1 \leq i \leq n-1$ dan $j=1,2$ maka titik-titik elemen $V\left(H_{v_{j, i} v_{j, i+1}}\right)$ tidak bertetangga dengan titik elemen $S$.

Agar kedua kondisi di atas tidak terjadi maka dipilih sebagai himpunan dominasi adalah $S=\left\{v_{1,2 t-1} ; t=1,2, \ldots,\left\lceil\frac{n}{2}\right\rceil\right\} \cup\left\{v_{2,2 t} ; t=1,2, \ldots,\left\lfloor\frac{n}{2}\right\rfloor\right\}$ dengan $|S|=\left\lceil\frac{n}{2}\right\rceil+\left\lfloor\frac{n}{2}\right\rfloor=n$.

Teorema 6. Jika $F_{n, k}$ adalah graf kembang api dan H adalah graf sebarang maka

$$
\gamma\left(F_{n, k} \diamond H\right)=\left\{\begin{array}{c}
n, \text { untuk } k=2 \\
n+\left\lfloor\frac{n}{2}\right\rfloor, \text { untuk } k>2
\end{array}\right.
$$

Bukti: Misalkan $F_{n, k}$ merupakan sebuah graf kembang api dengan himpunan titik $V\left(F_{n, k}\right)=$ $\left\{v_{i, j} ; i=1,2, \ldots n\right.$ dan $\left.j=1,2, \ldots k\right\}$ dan $H$ merupakan sebuah graf sebarang. Dalam hal ini $v_{1,1}$ dan $v_{n, 1}$ adalah penamaan untuk titik berderajat $2, v_{2,1}, \ldots, v_{n-1,1}$ untuk titik berderajat $3, v_{i, 2}$ untuk titik berderajat $k-1$, dan $v_{i, j}$ dengan $3 \leq j \leq k$ untuk titik berderajat 1 . Misalkan pula $E\left(F_{n, k}\right)=\left\{v_{i, 1} v_{i, 2} ; i=1, \ldots, n\right\} \cup\left\{v_{i, 1} v_{i+1,1} ; i=1, \ldots, n-1\right\} \cup\left\{v_{i, 2} v_{i, j} ; i=\right.$ $1, \ldots, n$ dan $j=3,4, \ldots k\}$. Diambil $S=\left\{v_{i, 2} ; i=1,2, \ldots n\right\} \cup\left\{v_{2 t, 1} ; t=1,2, \ldots\left\lfloor\frac{n}{2}\right\rfloor\right\}$. Untuk sebarang $x \in V\left(F_{n, k} \diamond H\right) \backslash S$ maka:

- $x=v_{i, j}$ untuk $1 \leq i \leq n$ dan $3 \leq j \leq k$. Dalam hal ini $x \sim v_{i, 2}$.

- $\quad x=v_{i, 1}$ dengan $i=2 t-1, t=1,2, \ldots\left\lfloor\frac{n}{2}\right\rfloor$ untuk $n$ genap atau $i=2 t+1, t=0,1, \ldots\left\lfloor\frac{n}{2}\right\rfloor$ untuk $n$ gasal. Dalam hal ini $x \sim v_{2 t, 1}$.

- $\quad x \in V\left(H_{v_{i, 2} v_{i, j}}\right)$ untuk $1 \leq i \leq n$ dan $1 \leq j \leq k$. Dalam hal ini $x \sim v_{i, 2}$.

- $\quad x \in V\left(H_{v_{i, 1} v_{i+1,1}}\right)$ untuk $1 \leq i \leq n-1$. Dalam hal ini $x \sim v_{2 t, 1}$.

Jadi $S$ himpunan dominasi dengan $|S|=n+\left\lfloor\frac{n}{2}\right\rfloor$. Andaikan ada $T \subseteq V\left(F_{n, k}\right)$ dengan $|T|<n+$ $\left\lfloor\frac{n}{2}\right\rfloor$. Jika ada $i$ sehingga $v_{i, 2} \notin T$ maka setiap $x \in V\left(H_{v_{i, 2} v_{i, j}}\right)$ untuk $1 \leq j \leq k$ tidak bertetangga dengan elemen $T$. Jika ada $i$ sehingga $v_{i, 1}, v_{i+1,1} \notin T$ maka setiap $x \in V\left(H_{v_{i, 1} v_{i+1,1}}\right)$ tidak bertetangga dengan elemen $T$. Keduanya menyebabkan $T$ bukan himpunan dominasi.

Untuk $k=2$ nilai bilangan dominasinya adalah $\gamma\left(F_{n, 2} \diamond H\right)=n$ dengan himpunan- $\gamma\left(F_{n, 2} \diamond H\right)$ adalah $\left\{v_{i, 1} ; i=1,2, \ldots n\right\}$.

Teorema 7. Jika $B_{n, k}$ adalah graf pohon pisang dan $H$ adalah graf sembarang maka 


$$
\gamma\left(B_{n, k} \diamond H\right)=\left\{\begin{array}{c}
n, \text { untuk } k=2 \\
n+1, \text { untuk } k>2
\end{array} .\right.
$$

Bukti: Misalkan $B_{n, k}$ merupakan sebuah graf pohon pisang dengan himpunan titik $V\left(B_{n, k}\right)=$ $\left\{v_{p}\right\} \cup\left\{v_{i, j} ; i=1,2, \ldots n\right.$ dan $\left.j=1,2, \ldots k\right\}$ dan $H$ merupakan sebuah graf sebarang. Dalam hal ini $v_{p}$ adalah titik berderajat $n, v_{i, 1}$ adalah titik berderajat $k-1, v_{i, 2}$ untuk titik berderajat 2 dan $v_{i, j}$ dengan $3 \leq j \leq k$ untuk titik berderajat 1 . Misalkan pula $E\left(B_{n, k}\right)=\left\{v_{p} v_{i, 2} ; i=1, \ldots, n\right\} \cup$ $\left\{v_{i, 1} v_{i, j} ; i=1, \ldots, n\right.$ dan $\left.j=2,3, \ldots, k\right\}$. Pada graf $B_{n, k} \diamond H$ berlaku:

(i) pada subgraf $v_{i, 1}+v_{i, j}+H_{v_{i, 1}, v_{i, j}}$ untuk semua $j, 1 \leq j \leq k$, titik $v_{i, 1}$ mendominasi semua titik lain pada subgraf tersebut.

(ii) titik $v_{p}$ mendominasi titik-titik pada subgraf $v_{p}+v_{i, 2}+H_{v_{p}, v_{i, 2}}$ untuk semua $i, 1 \leq i \leq n$. Memperhatikan dua kondisi tersebut, diambil himpunan $S=\left\{v_{p}\right\} \cup\left\{v_{i, 1} ; i=1,2, \ldots n\right\}$ sebagai himpunan dominasi. Dalam hal ini pengambilan titik $v_{p}$ dapat diganti dengan salah satu titik $v_{i, 2}$. Jelas $|S|=n+1$. Jika ada himpunan dominasi $T$ dengan $|T|<|S|$, misalkan $|T|=n$, maka berlaku:

- jika terdapat $i$ sehingga $v_{i, 1} \notin T$ maka semua titik $x \in H_{v_{i, 1}, v_{i, j}}$ dan semua titik $v_{i, j}$ untuk $1 \leq j \leq k$ tidak bertetangga dengan titik elemen $T$ yang lain.

- jika $v_{p}$ atau salah satu titik $v_{i, 2}$ bukan elemen $T$ maka titik $v_{p}$ tidak bertetangga dengan titik elemen $T$ yang lain.

Jadi $S$ adalah himpunan- $\gamma\left(B_{n, k} \diamond H\right)$. Untuk $k=2$ diambil $S=\left\{v_{i, 1} ; i=1,2, \ldots n\right\}$.

Hasil-hasil di atas, jika dibandingkan dengan Proposisi 1 dan Proposisi 4, memperlihatkan untuk sebarang graf $H$, jika $G$ graf terhubung maka $\gamma(G) \leq \gamma(G \diamond H)$. Syarat perlu dan cukup berlaku kesamaan disajikan berikut.

Teorema 8. Diberikan graf terhubung $G$ dan sebarang graf $H$. Misalkan $S$ merupakan himpunan$\gamma(G)$, berlaku $\gamma(G)=\gamma(G \diamond H)$ jika hanya jika untuk setiap $x y \in E(G), x \in S$ atau $y \in S$.

Bukti: Diketahui $\gamma(G)=\gamma(G \diamond H)$ dan $S$ juga merupakan himpunan- $\gamma(G \diamond H)$, maka berlaku $V(G \diamond H)-S \subseteq \cup_{v \in S} N(v)$. Andaikan ada $x y \in E(G)$ dengan $x \notin S$ dan $y \notin S$, maka $H_{x y} \cap\left(\cup_{v \in S} N(v)\right)=\varnothing \quad$ sehingga $\quad V\left(x+y+H_{x y}\right) \nsubseteq \cup_{v \in S} N(v) \quad$ yang mengakibatkan $V(G \diamond H)-S \nsubseteq \cup_{v \in S} N(v)$ sehingga timbul kontradiksi.

Sebaliknya jika untuk setiap $x y \in E(G)$ berlaku $x \in S$ atau $y \in S$ maka untuk setiap $v \in$ $V\left(x+y+H_{x y}\right)$ menyebabkan $v \sim x$ atau $v \sim y$. Akibatnya $V(G \diamond H)=\cup_{x y \in E(G)} V(x+v+$ $\left.H_{x v}\right)=\cup_{x \in S} N[x]$. Ini berarti $S$ merupakan himpunan $\gamma(G \diamond H)$ sehingga $\gamma(G)=\gamma(G \diamond H)$. 
Dari teorema di atas, diperoleh ekuivalensinya yaitu: Misalkan $S$ merupakan himpunan$\gamma(G)$ dari graf terhubung $G$. Untuk sebarang graf $H$ berlaku $\gamma(G)<\gamma(G \diamond H)$ jika hanya jika terdapat $x y \in E(G)$ dengan $x \notin S$ dan $y \notin S$.

Contoh untuk Teorema 8 adalah graf $C_{4} \diamond H$ untuk sebarang graf $H$, dengan $\gamma\left(C_{4}\right)=\gamma\left(C_{4} \diamond H\right)=$ 2 sedang untuk ekuivalensinya adalah graf $C_{5} \diamond H$ dengan $\gamma\left(C_{5}\right)=2$ tetapi $\gamma\left(C_{5} \diamond H\right)=3$.

Dengan memperhatikan Proposisi 5, diperoleh teorema berikut.

Teorema 9. Misalkan $G$ adalah graf terhubung dan $H$ adalah graf sebarang. Jika $G=K_{1}+P$ untuk suatu graf P maka

$$
(G \diamond H)=\left\{\begin{array}{r}
1, \text { jika } P \text { graf kosong } \\
1+\gamma(P \diamond H), \text { untuk yang lain }
\end{array} .\right.
$$

Bukti: Misalkan $K_{1}=\{v\}$ maka $v x \in E(G)$ untuk setiap $x \in E(P)$. Akibatnya $v$ mendominasi $\bigcup_{x \in P}\left(x+v+H_{x v}\right)$. Jika $P$ graf kosong maka $V(G \diamond H)=\bigcup_{x \in P} V\left(x+v+H_{x v}\right)$ sehingga $\quad v$ mendominasi $G \diamond H$. Jika $P$ bukan graf kosong, misalkan $S$ adalah himpunan- $\gamma(P \diamond H)$ sehingga $V(P \diamond H)-S \subseteq \cup_{v \in S} N(v)$. Di sisi lain $V(G \diamond H)=V(P \diamond H) \cup\left(\cup_{x \in P}\left(x+v+H_{x v}\right)\right)$. Oleh karena $v$ mendominasi $\bigcup_{x \in P}\left(x+v+H_{x v}\right)$ maka $V(G \diamond H)-(S \cup\{v\}) \subseteq \bigcup_{v \in S} N(v) \cup N(v)$. Ini berarti $S \cup\{v\}$ merupakan himpunan- $\gamma(G \diamond H)$.

Akibat 10. Misalkan $G$ adalah graf terhubung dan $H$ adalah graf sebarang. $\gamma(G \diamond H)=1$ jika hanya jika $G=S_{n}$.

\subsection{Bilangan Dominasi Jarak-2 Hasil Operasi Korona Sisi}

Jika konsep bilangan dominasi bertumpu pada ketetanggaan antara dua titik, maka konsep terebut diperluas menjadi bilangan dominasi jarak-2 dimana konsep ketentanggaan antara dua titik diperluas menjadi berjarak maksimum 2.

Teorema 11. Jika $P_{n}$ adalah graf lintasan dan $H$ adalah graf sebarang maka $\gamma_{\leq 2}\left(P_{n} \diamond H\right)=$ $\left\lceil\frac{n-1}{4}\right\rceil$ untuk $n>1$ dan $\gamma_{\leq 2}\left(C_{n} \diamond H\right)=\left\lceil\frac{n}{4}\right\rceil$ untuk $n \geq 3$

Bukti: Misalkan penamaan titik dan sisi graf lintasan seperti pada Teorema 1. Diambil $S=$ $\left\{v_{4 t-1} ; t=1, \ldots, k=\left\lceil\frac{n-1}{4}\right\rceil\right\}$. Untuk $n \equiv 2 \bmod (4)$, titik terakhir dari $S$ diambil $v_{4 t-2}$ bukan $v_{4 t-1}$. Untuk sebarang $x \in V\left(P_{n} \diamond H\right) \backslash S$ berlaku: $x=v_{4 t-3}$ atau $x=v_{4 t-2}$ atau $x=v_{4 t}$ atau $x \in$ $H_{v_{i} v_{i+1}}$. Jelas bahwa ketiga jenis titik tersebut berjarak 1 atau 2 terhadap titik $v_{4 t-1}$ sehingga $S$ 
merupakan himpunan dominasi jarak-2. Andaikan ada $T \subseteq V\left(P_{n}\right)$ dengan $|T|<k=\left\lceil\frac{n-1}{4}\right\rceil$ maka terdapat $v_{i}, v_{i+1} \in V\left(P_{n}\right)$ sehingga $d\left(v_{i}, T\right) \geq 2$ dan $d\left(v_{i+1}, T\right) \geq 2$. Akibatnya untuk setiap $x \in$ $H_{v_{i} v_{i+1}}$ berlaku $d(x, T)>2$.

Bukti sejalan untuk graf $C_{n} \diamond H$ dengan mengambil $S=\left\{v_{4 t+1} ; t=0,1, \ldots,\left\lceil\frac{n}{4}\right\rceil-1\right\}$ sebagai himpunan dominasi jarak-2.

Teorema 12. Jika $H$ adalah graf sebarang maka $\gamma_{\leq 2}\left(K_{n} \diamond H\right)=\gamma_{\leq 2}\left(K_{m, n} \diamond H\right)=$ $\gamma_{\leq 2}\left(K_{n_{1}, n_{2}, \ldots, n_{k}} \diamond H\right)=1$.

Bukti: Diambil salah satu titik dari graf $K_{n}$ semua titik lain pada graf $K_{n} \diamond H$ berjarak satu atau dua dari titik tersebut. Hal yang sama berlaku juga pada graf $K_{m, n} \diamond H$ ataupun $K_{n_{1}, n_{2}, \ldots, n_{k}} \diamond H$.

Teorema 13. Jika $L_{n}$ adalah graf tangga dan $H$ adalah graf sebarang maka $\gamma_{\leq 2}\left(L_{n} \diamond H\right)=$ $\left\lceil\frac{n}{3}\right\rceil$ untuk $n>1$.

Bukti: Misalkan penamaan titik dan sisi seperti pada Teorema 5. Untuk sebarang titik $v_{1, t} \in$ $V\left(L_{n}\right)$, titik tersebut mendominasi jarak-2 titik-titik $v_{1, t-2}, v_{1, t-1}, v_{1, t+1}, v_{1, t+2}$, juga titik $v_{2, t-1}, v_{2, t}, v_{2, t+1}$. Selain itu juga mendominasi jarak-2 semua titik-titik elemen dari $H_{v_{1, i} v_{1, i+1}}$ untuk $t-2 \leq i \leq, t+1, H_{v_{2, i} v_{2, i+1}}$ untuk $t-1 \leq i \leq t$, dan $H_{v_{1, i} v_{2, i}}$ untuk $t-1 \leq i \leq t+1$. Dipilih himpunan dominasi jarak-2 sebagai berikut. Misalkan $I=\left\{1,2, \ldots,\left\lceil\frac{n}{3}\right\rceil\right\}$. Dibentuk $A=$ $\left\{v_{1,3 t-1} ; t \in I, t\right.$ gasal $\}$ dan $B=\left\{v_{2,3 t-1} ; t \in I, t\right.$ genap $\}$. Selanjutnya diambil $S=A \cup B$. Semua titik elemen $V\left(L_{n} \diamond H\right) \backslash S$ didominasi jarak-2 oleh satu titik elemen $S$, kecuali titik -titik elemen $V\left(L_{n}\right)$ yang berjarak 2 dari titik elemen $S$ didominasi jarak-2 oleh dua titik, satu dari elemen $A$ dan yang lain dari elemen $B$ terdekat. Pengambilan titik akhir $v_{i, 3 t-1}$ untuk $t=\left\lceil\frac{n}{3}\right\rceil$ berlaku untuk $n \not \equiv$ $1 \bmod (3)$ sedang untuk $n \equiv 1 \bmod (3)$ titik akhir yang diambil adalah $v_{i, n}$.

Teorema 14. Jika $F_{n, k}$ adalah graf kembang api, $B_{n, k}$ adalah graf pohon pisang dan $H$ adalah graf sebarang maka

$$
\gamma_{\leq 2}\left(F_{n, k} \diamond H\right)=\left\{\begin{array}{c}
{\left[\frac{\mathrm{n}}{3}\right\rceil, \text { untuk } k=2} \\
n, \text { untuk } k>2
\end{array} \text { dan } \gamma_{\leq 2}\left(B_{n, k} \diamond H\right)=\left\{\begin{array}{l}
1, \text { untuk } k=2 \\
n, \text { untuk } k>2
\end{array} .\right.\right.
$$

Bukti: Misalkan penamaan titik dan sisi pada graf $F_{n, k}$ sama seperti pada Teorema 6 . Diambil $S=$ $\left\{v_{i, 1} ; i=1,2, \ldots n\right\}$ maka untuk sebarang $x \in V\left(F_{n, k} \diamond H\right) \backslash S$ tentu $x$ berjarak satu atau dua 
terhadap titik $v_{i, 1}$ untuk suatu $i$. Andaikan ada $T \subseteq V\left(F_{n, k}\right)$ dengan $|T|<n$ maka terdapat $i$ sehingga semua titik $v_{i, j} \notin T$ untuk $1 \leq j \leq k$. Akibatnya setiap titik $v_{i, j}$ untuk $3 \leq j \leq k$ memenuhi $d\left(v_{i, j}, T\right)>2$. Untuk $k=2$ nilai $\gamma_{\leq 2}\left(F_{n, 2} \diamond H\right)=\left\lceil\frac{n}{3}\right\rceil$ dengan himpunan- $\gamma_{\leq 2}\left(F_{n, 2} \diamond H\right)$ adalah $\left\{v_{3 t-1,1} ; t=1,2, \ldots\left[\frac{n}{3}\right]\right\}$. Khusus untuk $n \equiv 1 \bmod (3)$, titik akhir diambil $v_{n, 1}$.

Bukti sejalan untuk graf $B_{n, k} \diamond H$ dengan himpunan- $\gamma_{\leq 2}\left(B_{n, k} \diamond H\right)$ adalah $\left\{v_{i, 2} ; i=1,2, \ldots n\right\}$, khususnya untuk $k=2$ himpunan- $\gamma_{\leq 2}\left(B_{n, 2} \diamond H\right)$ adalah $\left\{v_{p}\right\}$.

Hasil-hasil Teorema 11 sampai Teorema 14 dibandingkan dengan Proposisi 3 dan Proposisi 6 menunjukkan bahwa $\gamma_{\leq 2}(G) \leq \gamma_{\leq 2}(G \diamond H)$, untuk sebarang graf $H$. Kesamaan berlaku seperti di bawah ini.

Teorema 15. Diberikan $G$ graf terhubung dan $S$ merupakan himpunan- $\gamma_{\leq 2}(G)$. Untuk sebarang graf $H, \gamma_{\leq 2}(G)=\gamma_{\leq 2}(G \diamond H)$ jika hanya jika untuk setiap $x y \in E(G)$ berlaku $x \sim u$ atau $y \sim u$ untuk $u \in S$.

Bukti: Misalkan $S$ juga merupakan himpunan- $\gamma_{\leq 2}(G \diamond H)$. Andaikan ada $x y \in E(G)$ dengan $x \nsim$ $u$ dan $y \nsim u$ untuk $u \in S$ maka $d(x, u) \geq 2$ dan $d(y, u) \geq 2$. Akibatnya, untuk sebarang $v \in$ $H_{x y}$ berlaku $d(v, u) \geq 3$ sehingga $S$ bukan himpunan dominasi jarak-2 dari $G \diamond H$.

Sebaliknya jika untuk setiap $x y \in E(G)$ berlaku $x \sim u$ atau $y \sim u$ untuk $u \in S$ maka untuk setiap $v \in H_{x y}$ berlaku $d(v, u) \leq 2$. Akibatnya untuk sebarang $w \in V(G \diamond H) \backslash S$ berlaku $d(v, S) \leq 2$ yang berarti $S$ merupakan himpunan dominasi jarak-2 dari $G \diamond H$.

Dari Teorema 15 di atas, diperoleh ekuivalensinya yaitu: untuk $G$ graf terhubung, $H$ graf sebarang, dan $S$ suatu himpunan- $\gamma_{\leq 2}(G)$ berlaku: $\gamma_{\leq 2}(G)<\gamma_{\leq 2}(G \diamond H)$ jika hanya jika terdapat $x y \in E(G)$ dengan $x \propto u$ dan $y \nsim u$ untuk $u \in S$. Teorema 15 dan ekuivalensinya dapat digunakan untuk melihat apakah sebuah graf hasil operasi korona sisi mempunyai bilangan dominasi jarak-2 yang sama atau berbeda dengan bilangan dominasi jarak-2 dari graf induknya.

Teorema 16. Untuk sebarang graf $H$, jika graf terhubung $G$ sehingga $G=K_{1}+P$ untuk suatu graf $P$ maka $\gamma_{\leq 2}(G \diamond H)=1$.

Bukti: $\quad$ Misalkan $\quad K_{1}=\{v\} . \quad V(G \diamond H)=V\left(\left(K_{1}+P\right) \diamond H\right)=\left(\bigcup_{w \in P}(w+v+\right.$ $\left.\left.H_{w v}\right)\right) \cup V(P \diamond H)=\left(\bigcup_{w \in P}\left(w+v+H_{w v}\right)\right) \cup\left(\bigcup_{x y \in E(P)}\left(x+y+H_{x y}\right)\right)$. Selanjutnya untuk setiap $w \in P$ berlaku $d\left(v, w+v+H_{w v}\right)=1$ sedang untuk setiap $x y \in E(P)$ berlaku $d\left(v, x+y+H_{x y}\right)=d(v, x)+d\left(x, x+y+H_{x y}\right)=1+1=2$. Akibatnya $d(v, V(G \diamond H)) \leq 2$ sehingga $\{v\}$ merupakan himpunan- $\gamma_{\leq 2}(G \diamond H)$. 


\section{Simpulan}

Dari pembahasan di atas disimpulkan bahwa bilangan dominasi graf hasil korona sisi mempunyai nilai yang tidak kurang dari bilangan dominasi graf induknya. Hal yang sama juga berlaku untuk bilangan dominasi jarak-2. Nilai bilangan dominasi graf hasil korona sisi $G \diamond H$ akan sama dengan nilai bilangan dominasi graf induk $G$ jika hanya jika pada setiap sisi graf induk, salah satu titiknya menjadi elemen himpunan- $\gamma(G)$. Disamping itu, nilai bilangan dominasi jarak-2 graf hasil korona sisi $G \diamond H$ akan sama dengan nilai bilangan dominasi jarak-2 graf induk $G$ jika hanya jika pada setiap sisi graf induk, salah satu titiknya bertetangga dengan elemen himpunan- $\gamma_{\leq 2}(G)$.

\section{Daftar Pustaka}

[1] P. Pavlič and J. Žerovnik, "A note on the domination number of the cartesian products of paths and cycles," Kragujev. J. Math., vol. 37, no. 2, pp. 275-285, 2013.

[2] C. E. Go and S. R. jun. Canoy, "Domination in the corona and join of graphs.," Int. Math. Forum, vol. 6, no. 13-16, pp. 763-771, 2011.

[3] A. Klobucar, "Domination numbers of cardinal product," Math. Slovaca, vol. 49, no. 4, pp. 387-402, 1999.

[4] D. Kuziak, M. Lemanska, and I. G. Yero, "Domination related parameters in rooted product graphs," pp. 1-18, 2012.

[5] S. K. Vaidya and N. J. Kothari, "Distance \$k\$-domination in some cycle related graphs," Miskolc Math. Notes, vol. 19, no. 2, p. 1223, 2018.

[6] E. Prathibha, S. P. Missier, and A. A. Kinsley, "Algorithms to determine the distance-t dominating sets of ES(n, k)," Procedia Comput. Sci., vol. 47, no. C, pp. 342-350, 2015.

[7] G. Chartrand and L. Lesniak, "Graphs \& Digraphs," p. 429, 2000.

[8] T. W. Haynes, S. T. Hedetniemi, and P. J. Slater, Fundamental of Domination in Grpahs. 1998.

[9] Y. Hou and W. C. Shiu, "The Spectrum of The Edge Corona of Two Graphs," Electron. J. Linear Algebr., vol. 20, pp. 586-594, 2010.

[10] R. Davila, C. Fast, M. A. Henning, and F. Kenter, "Lower bounds on the distance domination number of a graph," Contrib. to Discret. Math., vol. 12, no. 2, pp. 11-21, 2017. 